\title{
Manado children's choice echo trumpet (review aspects of establishment and development)
}

\author{
Meyny S. C. Kaunang*), Lucylle Takalumang \\ Manado State University Tondano, Indonesia
}

\begin{tabular}{l} 
Article Info \\
\hline Article history: \\
Received Aug $12^{\text {th }}, 2021$ \\
Revised Sept $20^{\text {th }}, 2021$ \\
Accepted Oct $26^{\text {th }}, 2021$ \\
\hline
\end{tabular}

\section{Keyword:}

Children's choir

Manado trumpet

Chorus management

\begin{abstract}
The purpose of this study was to examine and describe the children's choir of Gema Trumpets, review and how the process of making the Children's Choir of Gema Sangkakala Manado, How is the process of fostering the Children's Choir of Gema Sangkakala Manado, What are the factors that hinder the process? Ordering and coaching the Manado Echo Sangkakala Children's Choir, and What efforts have been made to overcome the obstacles to ordering and coaching the Echo Trumpets Children's Choir. The research method used in this study is qualitative. Data technique is done by observation, interview, documentation study. coaching, namely: After analyzing the data, it was concluded that The reservation of the Gema Sangkakala Manado children's choir was a response to the public's interest, especially choir observers to accommodate the potential of children who have interests and talents in senior vocals, especially in the choir., as part of the development of the organization (Studio) to contribute to fostering children's attitudes and behavior through the chorus, to motivate in general in cultivating and attracting children's interest in their love of good singing skills through praise, Age limits and parents, as well as children in the Choir by showing the impact of fostering children on a changing process, the management of the process always requires substantial funds by relying only on non-permanent donors, and Efforts which were carried out to overcome various obstacles in the choir, among others, recruiting members followed by $b$. interviews both for children and parents, involving parents in the preparation of activity programs that are tailored to the child's schedule, fundraising is carried out at any time including scheduling concert programs that are held regularly.
\end{abstract}

(C) 2021 The Authors. Published by IICET.

This is an open access article under the CC BY-NC-SA license (https://creativecommons.org/licenses/by-nc-sa/4.0)

\section{Corresponding Author:}

Meyny S. C. Kaunang,

Universitas Negeri Padang

Email: meynykaunang@unima.ac.id

\section{Introduction}

Choir as part of the art of vocal music has been widely known among the public, especially in the city of Manado, and recently its development is growing rapidly. This is a sign of the increasing public appreciation of the Choir itself and this public appreciation can be seen both in terms of the quality of its presentation and the quantity of its growth. Today, the choirs in Manado in particular, are no longer dominated by adult mixed choir groups, but the development of choir groups has expanded, which is not only dominated by adult mixed choirs but has also expanded to other choirs such as youth, youth, as well as children. 
The increase in choral groups is certainly based on reasons and goals that differ from one group to another. But the beginning of group formation is usually caused by the same reasons, such as an interest in something. This is in line with what was stated by Theodore Newcomb in Miftah Thoha (2003; 81), which states that: a person is attracted to another based on the similarity of attitudes in responding to a goal that is relevant to one another. The origin of the formation of a group usually begins with a desire, goal, interest in a particular thing. And what is very important in understanding the formation of groups based on the practical reasons above is that this group is expected to provide satisfaction to the basic needs of the people who group it.

The impact of social change in society is to realize the importance of choir development which must be started from an early age. This can be seen from the increasing enthusiasm of parents in introducing music to their children. Realizing that the formation and development of a child's sense of musicality for the development of the child's personality require good handling and is not only personal or personal from the parents, the child also needs to be allowed to socialize through other formal groups that are considered competent. Observing the children's choir groups in Manado they have developed well, in the sense that both the presentation and the growth are very fast.

Parents believe that music, especially the choir, will have a positive impact on children's development. This is in line with what was stated by A. Soetanta SJ, who said that: "singling solo can make children more confident and dare to appear in public. Furthermore, singing in a choir will be able to create a sense of togetherness and social sensitivity. In the choir children learn not to stand out alone and to sing properly so as not to damage the harmony of the voice" (2005:29). This opinion is also in line with what was stated by Ronald Pohan who stated that: "experiences and deepening of musical knowledge will produce self-confidence in children" (1995: 4).

Understanding the descriptions stated above, that singing or chorusing has a very important position in a child's life. On the other hand, that with choir activities, children will have more opportunities to expand their association by making many friends, learning and training themselves to be disciplined, independent and gain more experience, especially music experience.

He will find musical experiences for children, starting from practicing together in singing, singing praises, holding concerts both in town and outside the city, as well as participating in choir festivals. Realizing the importance of forming and fostering a child's sense of musicality for the development of the child's personality requires good handling and not only personal or personal from the parents, but the child also needs to be allowed to socialize through other formal groups that are considered competent. This means that children need a special forum or organization related to musical or choral activities because through a competent forum or organization they usually have one. Standard procedures related to the formation and coaching process. Observing the children's choir groups that exist in Manado today they have developed well, in the sense that both the presentation and the growth are very fast.

In the past, children's choirs were formed and prepared only for festivals in the form of competitions. However, in its current development, it is no longer solely intended for festivals as intended above, but nowadays many children's choirs are also formed to fill praise in the church and to improve and maintain the quality of their sound or voice.

The existence or existence of a children's choir that has been formed usually has problems that must be faced. These problems are usually related to how to maintain and improve the quality of the choir as well as the achievement of the goals set by the children's choir group. At least this problem can be found in one of the Gema Sangkakala choir art studios in Manado.

Gema Sangkakala Art Studio is an organization or choir group in Manado that has long existed in the Choir environment. The existence of Gema Sangkakala is an organization that has given a dominant color to the development of the choir both within the choir environment in North Sulawesi, nationally, and at the international level. The establishment of the Gema Sangkakala Art Studio was intended to accommodate or facilitate the talents of young people at that time. Things that are done by holding training continuously to maintain and improve the quality of the choir.

This literature review was carried out as the first step for researchers before conducting deeper research activities in the field, namely: 1) Rumambi, J., in 2007 with the title "Christy Choir from the Management Aspect". Reviewing management issues in the Choir. This paper relates to research that is currently being carried out in the process of formation, especially in management issues; 2) Mailensun, Christy N., in 2008 entitled "Children's Education in terms of the Role of Parents and Schools" in his writings, Mailensun focuses more on his research with children's music education which is devoted to the scope of education in schools. In contrast to this study, where the study focuses more on children's music within the choir; 3) Pohan, Ronald., 
in his paper entitled: Judging Techniques and Choir Development at Church Music Workshops throughout Eastern Indonesia who explained that, experiences and deepening of musical knowledge in the formation and development of Choirs; 4) Mokodompis, A., in 2008, raised the issue of the process of formation, function, and development of the GMIM Getsemani Telling Bawah mixed choir, which took place in Telling Bawah, Manado.

The study of these studies is stated based on having similarities with this study, namely in terms of the object of research in the Choir, but the research subjects who are mainly used as data sources and the location or place of research are different. Based on the description of the background above, it can be understood that it is very difficult to maintain a choir, especially a children's choir. However, the choir group "Gema Sangkakala Children's Choir" has been able to survive since its establishment and is even more active in the choir scene.

The discrepancy encountered is what attracts researchers to study scientifically through a study, with the title: "Echo of the Manado Children's Choir, An Overview of Aspects of Formation and Guidance". Based on the description above, the problem is formulated as follows: 1) What is the process of forming the Manado Trumpet Echo Choir?; 2) How is the process of developing the Manado Sangkakala Choir for children?; 3) What are the factors that hinder the children's choir Gema Sangkakala Manado?; 4) What are the efforts made to overcome obstacles in the process of forming and fostering the Manado Gema Sangkakala Children's Choir?

The purpose of this paper is to research the application of suggestions in Choir conducting techniques according to Perry Romanian. The purpose of this paper is: 1) To provide an overview of how to form a choir, especially the children's choir, Gema Sangkakala; 2) To provide an overview of the process of developing the Manado Sangakakala Choir for the Children's Choir; 3) To provide an overview of the inhibiting factors in the process of forming and fostering the Manado Sangkakala Echo Choir; 4) To provide an overview of the efforts made to overcome obstacles in the process of fostering the Manado Sangkakala Children's Choir.

Scientifically, it is in the context of contributing to the development of theory and as a refinement of the concept concerning the Choir and to the development of the Drama, Dance, and Music Study Program (Sendratasik). Practical Benefits: 1) As information and input for the Gema Sangkakala Manado art studio, especially the children's choir, where the results of this study are expected to be able to understand more deeply the advantages and disadvantages; 2) As input for other researchers to carry out further research.

\section{Method}

In connection with the problem of this research, namely to describe as it is about the formation and development of the Manado Sangkakala Children's Choir, the researchers used a qualitative research method or approach. The qualitative approach according to Moleong (1998), in principle is observing the behavior of people in their environment, interacting with them, and trying to understand their activities with the world around them. The characteristics of a qualitative approach, according to Bogdan and Biglen (1998), are (a) having a natural setting as a data source and the researcher acting as a key instrument, (b) descriptive research, (c) more concerned with the process than the product alone, (d) inductive analysis, (e) more concerned with meaning, meaning that meaning is something essential in qualitative research.

The location of this research is in the Ranotana village, Sario district, Manado City, and the object of research is the Gema Sangkakala children's choir at the Gema Sangkakala Choir Art studio. The techniques used in this data collection are: (a) in-depth interviews, (b) participatory observations, and (c) documentation studies.

In-depth interviews, intended to obtain constructions that are happening now about people, events, organizational activities, feelings, motivations, confessions, concerns, and so on. (Sherman and Webb, 1990:29). Participating observation, Goetz and Lecompte in Mantja (1990:77) states that: Participatory observation is a process in which the researcher enters a certain setting or atmosphere to make observations about events in an interconnected setting. Documentation studies, collect data from non-human sources, namely in the form of documents, archives, which are closely related to fakes and sub. Research focus.

Checking the validity of the data is something important in qualitative research because it will guarantee the reliability of the data. The data are analyzed in the form of words, sentences, or paragraphs which are stated in the form of a descriptive narrative. Analysis based on the application of descriptive analysis techniques according to Miles and Huberman (1992:20). 
Thus, after all the data that has been checked and analyzed from various sources, both directly and indirectly, starting from interviews, literature studies, and even literature, recordings, videos, after that they are researched, understood, clarified, evaluated, interpreted, and described as they should be. and the results of the description will be concluded inductively or inductively, moreover, it will be reported and accounted for scientifically in the form of published scientific papers.

\section{Results and Discussions}

\section{Children's voice echoes trumpet overview aspects of establishment and development Formation of Children's Choir}

In the Indonesian Dictionary, Formation can be defined as a process, method, act of forming. Meanwhile, the process or method can be interpreted as a series of actions, manufacture, or processing that produces a product, and in this case, it is associated with the choir, especially the Children's Choir Gema Sangakkara. The initial process until the formation of the Gema Sangkakala Children's Choir, here is a description of the data obtained through interviews with researchers and respondents who stated that the basic idea of forming a children's choir started from the appearance of an adult choir in filling praises in several places, so that several thoughts emerged. To form a special children's choir, it is also following the purpose of the formation of this art studio, which is to testify through the singing talent that is given to each person, and that talent is not only for adults but also children.

Apart from the respondent's statement above, the formation of the children's choir is a contribution from the thoughts of several community choir observers, such as what was stated by the respondent, that to become a good choir requires treatment from an early age or childhood. It was further said that during this childhood, it is very necessary to inculcate positive values to form good behavior, then this effort is to develop the child's potential as a provision for both his intellectual skills and as a provision for his mentality in entering society in the future. on the other hand, this childhood must be filled with positive activities such as songs whose poems contain religious themes.

The background to the formation of this children's choir, apart from what has been stated above, is that the formation of this choir is the answer to the wishes of some parents who yearn for a place that professionally handles the talents possessed by several children, especially about singing. Every church (congregation) has a special place for children's groups. But in reality, the forum does not specifically handle or develop children's potentials so that these potentials are not developed and not utilized. This is understandable because those entrusted with handling children's activities are not supported by several special skills such as the ability to train children to sing well. Until now, there are very few types of children's choirs, especially in this area. Both in terms of the continuity of the group and in terms of its only temporary development. This can be seen from the appearance of children's choir groups which can be observed especially in churches. Their appearances can be said to be very few. Even if there is, what is displayed seems to just fill the show. Children love to sing. So parents want their children to sing well. For this reason, as parents, we want a forum that can provide good direction and handling so that children can not only sing well, they are also able to be disciplined. For this reason, parents provide full support for this organization to form a special children's choir group. Children's choir has its beauty. In addition to their very beautiful voice, children's voices have a special characteristic that is bright and clear. So that anyone who hears and witnesses it will give a very deep assessment and impression. As told by the parents who stated that from several times they watched the performance of a choir, they were very interested because it was very different from the adult choir that they had often heard. So that interest raises support for the formation of a forum that can foster children's voices properly and correctly.

Nowadays, the appearance of a children's choir that looks good, usually can only be seen when there is a competition or competition conducted by a certain church organization, and after that the children's choir is no longer heard. So the idea of forming a children's choir and being encouraged by parents who watch the choir gives a good idea for this organization to form a permanent choir. Because the problem that will be faced is how it continues. Because the choir whose members are children who take turns every year because they will get older. Observing the problems mentioned above, good planning is needed, such as the respondent's statement that to form a children's choir, its members are taken with several requirements, especially the age of one year below the maximum age. With other selection stages such as classification of low and high voice types. To get several members according to need, socialization or announcements are held either through organizational administrators, or through notifications in churches, or open to the general public who want their children to form a choir. stages of interviews both with children and with parents. With several other stages, essentially parents are very enthusiastic and support these efforts, as stated by parents that the consequences are for the good and competence of their children so that to develop the abilities and talents of 
the children, parents should strive for it, both in terms of time, financial consequences, as well as supporting the efforts planned by the management14.

\section{Children's Choir Development.}

As has been stated in the previous chapters, the purpose of developing the children's choir is not only to be able to sing well but also to be the focus of attention in the development of the attitudes and behavior of the members. This is as stated by the respondents that to become a good singer can be achieved by practicing singing through a scheduled program, and all members can do that. But to achieve this, one must go through a process related to mental attitudes, such as discipline in the training schedule, being faithful in following the overall training program, and complying with organizational rules as stipulated in the articles of association and by-laws of the organization, especially the choir. child.

In line with this opinion, other respondents also support the opinion that before the choir members enter the core or technical training process, they are first taught to understand the rules of the organization's members and this is stated not only for the child but also for the child's parents. . As parents, we understand what the responsibilities of parents and their children as members of the choir are. But as parents, it is necessary to accompany them, although not always so that they can be independent. So in this organization, parents are very supportive because coaching for children is not only focused on technical training, they are also taught responsibility. In line with this opinion, other parents also support that their children are not only taught how to sing well but are also taught how to be independent, especially for children who are above the average age. Children are also taught discipline, especially in keeping time. practice, as well as being responsible for self-regulation in preparing equipment ranging from song texts, clothing in this choir group, of course, is singing technical coaching.

Menjadi seorang penyanyi yang baik khususnya penyanyi paduan suara, hal-hal yang menyangkut teknis perlu dikuasai. Ini dimaksudkan bahwa untuk membawakan suatu lagu secara bersama memerlukan pelatihan yang intensif, mulai dari pembentukan suara yang dimulai dengan pembagian suara menurut wilayah suaranya, pembentukan vokal yang dimulai dari latihan-latihan vokalisi, latihan membaca notasi-notasi yang dimulai dengan notasi-notasi sederhana, sampai pada latihan- latihan fisik seperti pelemasan dan pemanasan untuk menunjang pencapaian penyanyian yang baik.

According to respondents, choir practice requires special attention from each member of the singer, especially in terms of technical singing. In technical coaching, to get maximum results requires extra training, which is not only at the time of meetings which are held periodically according to the schedule but requires additional time that must be carried out, namely when they are at home or anywhere when they are in a good atmosphere. allow.

\section{Barriers to Forming and Coaching}

Every organization has obstacles and challenges in the process, both in the formation and in the implementation process. Likewise, the Gema Sangkakala children's choir group, which consists of children from various environmental backgrounds. These obstacles and challenges can be encountered as described by the following respondents according to the results of interviews and observations of researchers.

It is realized that not always everything that has been programmed runs smoothly without obstacles or even something that is not achieved by the goals that have been set. As in the case of the initial formation which was carried out with a member selection system in recruitment activities, which were netted a lot, but in the coaching process some resigned without notification, obstacles in locations far from the training ground when the stage was hampered by school exam times, there were sick, and many things that are closely related to other children's activities that coincide with the program that has been arranged.

In addition to the obstacles mentioned above, other obstacles are related to funding, both in incentives for the rehearsal process, procurement of singer uniforms, as well as when conducting tours outside the region that require a lot of funds, where fundraising involves extra work from choir administrators, but also involve extra time for children with concerts in raising funds.

\section{Efforts to Overcome Barriers}

Forming and nurturing a choir like this children's choir is essentially a vocation, especially in serving God, intending to form and foster potentials in the form of vocal artistic talents possessed by children for the glory of God the giver of these talents.

For this reason, when faced with obstacles such as those mentioned above, as an organization, of course, we struggle with all of them while trying to find solutions to these problems, and during the journey of this choir from its establishment until now this children's choir still exists in providing service in the form of testimony through the praise of God to the congregation in particular and society in general. 
Efforts were made to overcome obstacles in the recruitment process, among others, a recruitment method was held by interviewing prospective members and their parents, by stating the goals and consequences of becoming a member of the Gema Sangkakala children's choir. Likewise, in the process of preparing programs, both training, and performances, or tours outside the region, it is adjusted.

\section{Conclusions}

The explanation of the Echo Trumpets Choir in terms of the aspects of formation and development, as previously stated, starting from the introductory chapter to the discussion chapter, the researcher can draw several conclusions as follows: 1) That the formation of this children's choir started from the mixed choir of Gema Sangkakala Adult who was motivated and contributed ideas from several community observers of the choir through the appearance of an adult choir; 2) It is a response from the management of the choir studio organization from the wishes of several parents who yearn for a forum that professionally handles the talents possessed by some children, especially with singing; 3) The limited number of children's choir groups in the community, and the emerging groups are temporary and their presence shows that they are not well organized; 4) The development of the Gema Sangkakala children's choir is aimed at sharpening skills in terms of singing techniques, but not merely to become a group of good singers, but also to be the focus of attention in the development of attitudes and behavior of members, such as self-discipline, responsibility. togetherness values, mutual help, and other social attitudes; 5) The main purpose of coaching is essential to give testimony in the form of praise within the church, as well as taking part in certain events as motivation to maintain children's love for the choir, as well as to test or evaluate the development of the choir; 6) Another goal is to maximize and develop the potential of children according to their talents, more specifically in vocal arts; 7) Choir members are generally of school age, so there are often children's choir organization programs along with school activities, which also results in some members being unable to participate in activities in the children's choir; 8) Some staging activities, especially out-of-region tours, cannot be carried out due to limited funds; 9) Efforts were made to overcome various obstacles in the choir, among others, recruiting members followed by interviews for both children and parents, involving parents in the preparation of activity programs tailored to the children's schedule, fundraising carried out at any time including scheduling concert programs that were held regularly.

\section{References}

Becker, N., \& Goffi-Fynn, J. (2016). Discovering Voices: Expanding Students'musical And Vocal Ideals In An Urban Community Children's Choir. The Choral Journal, 56(7), 8.

Bogdan, R.C. \& Biklen S.K., 1998. Qualitative Research for Education. An Introduction to Theory and Methods, Boston:Allyn and Bacon,Inc.

Gunarsa, Singgih D., 1992. Psikologi Perkembangan. Jakarta:PTBPK Gunung Mulia.

Haugland, S. L. (2013). Crowd control: Classroom management and effective teaching for chorus, band, and orchestra. R\&L Education.

Jamalus, 1988. Musik 4. Depdikbud, Jakarta.

Jiang, Y. (2021). Crystal Children's Choir: A Case Study on Choral Music Reaching Younger Generations (Doctoral dissertation, Drexel University).

Lindl, C. B. (2018). Chinese American adolescent identity in a children's choir: An exploratory study. Bulletin of the Council for Research in Music Education, (218), 35-48.

Mailensun, Christy N.,2007. Skripsi: Pendidikan Musik AnakDitinjau Dari Peran Orang Tua Dan Sekolah. FBS: Unima.

Miles, Matthew B.,\& Huberman A.M., 1992. Qualitative DataAnalysis,(Terjemahan:Tjetjep Rohendi Rohidi),Jakarta:.UI Press.

Mokodompis, A., Tahun 2008, Skripsi: Paduan Suara CampuranJemaat GMIM Getsemani Teling Bawah Tinjauan ProsesPembentukan,Fungsi dan Perkembangan. FBS: Unima.

Moleong,Lexy.,1988. Metode Penelitian Kualitatif,Bandung:Remaja Rosdakarya.

Nasution, S., 1988.Metode Penelitian Naturalistik Kualitatif,Bandung:Tarsito.

Pamadhi, Hadjar., dkk., 2008. Pendidikan Seni di SD. Jakarta:Universitas Terbuka.

Pohan,Ronald.,2007. Makalah: Teknik Penjurian Dan PembinaanPaduan Suara. LokakaryaMusik Gereja SeIndonesiaTimur.

Potter, H. W. (2005). Perspectives on the American Children's Choir: Comparing the Ideas of Jean Ashworth Bartle, Helen Kemp, Henry Leck, and Doreen Rao. The University of North Carolina at Greensboro.

Ramadhani,Succi: http://nison23rd.multiply.com/journal/item/14: pengaruh musik pada kepribadian anak. 
Rensink-Hoff, R. (2012). An Interview with Zimfira Poloz, Children's Choir Conductor and Educator. The Canadian Music Educator, 53(3), 14.

Rumambi, J., 2007. Skripsi: Paduan Suara Militia Christy DitinjauDari Aspek Manajemen.FBS:Unima.

Sabri,Alisuf M.,1992.PengantarPsikologiUmum \& Perkembangan. Jakarta: Pedoman Ilmu Jaya.

Sherman, R.R.,Webb, R. B.,1990.Qualitative Research inEducation:Focus and Methods, New York: The FalmerPress.

Sitompul, Binsar.,1986.Paduan Suara Dan Pemimpinnya.

Thoha,Miftah.,2003. Perilaku Organisasi. Jakarta:Raja GrafindoPersada.

William, Mantja.,1990. Etnografi: Disain Penelitian ManajemenPendidikan:Malang:PPsIKIP Malang.

Woo, S. (2015). Imagining Kin: Cold War Sentimentalism and the Korean Children's Choir. American Quarterly, 67(1), 25-53.

Yunanto, R. P., \& Yong-Shik, L. (2021). Color Formation of Musical Compositions of Children's Choir "Vocalista Angels". Dewa Ruci: Jurnal Pengkajian dan Penciptaan Seni, 16(2), 91-97. 